\title{
Association between IL-18 gene polymorphisms and biopsy-proven giant cell arteritis
}

\author{
Rogelio J Palomino-Morales ${ }^{1}$, Tomas R Vazquez-Rodriguez ${ }^{2}$, Orlando Torres ${ }^{1}$, Inmaculada C Morado ${ }^{3}$, \\ Santos Castañeda ${ }^{4}$, Jose A Miranda-Filloy ${ }^{2}$, Jose L Callejas-Rubio ${ }^{5}$, Benjamin Fernandez-Gutierrez ${ }^{3}$, \\ Miguel A Gonzalez-Gay ${ }^{6 \dagger}$, Javier Martin ${ }^{1 * \dagger}$
}

\begin{abstract}
Introduction: The objective was to investigate the potential implication of the $I L 18$ gene promoter polymorphisms in the susceptibility to giant-cell arteritis (GCA).

Methods: In total, 212 patients diagnosed with biopsy-proven GCA were included in this study. DNA from patients and matched controls was obtained from peripheral blood. Samples were genotyped for the IL18-137 G>C (rs187238), the IL18-607 C>A (rs1946518), and the IL18-1297 T>C (rs360719) gene polymorphisms with polymerase chain reaction, by using a predesigned TaqMan allele discrimination assay.

Results: No significant association between the IL18-137 G>C polymorphism and GCA was found. However, the IL18 -607 allele A was significantly increased in GCA patients compared with controls (47.8\% versus $40.9 \%$ in patients and controls respectively; $P=0.02 ; \mathrm{OR}, 1.32 ; 95 \% \mathrm{Cl}, 1.04$ to 1.69 ). It was due to an increased frequency of homozygosity for the IL18 -607 A/A genotype in patients with GCA (20.4\%) compared with controls (13.4\%) (IL18 -607 A/A versus IL18$607 \mathrm{~A} / \mathrm{C}$ plus IL18-607 C/C genotypes: $P=0.04 ; \mathrm{OR}, 1.59 ; 95 \% \mathrm{Cl}, 1.02$ to 2.46$)$. Also, the IL18-1297 allele $\mathrm{C}$ was significantly increased in GCA patients (30.7\%) compared with controls (23.0\%) $(P=0.003 ; \mathrm{OR}, 1.48 ; 95 \% \mathrm{Cl}, 1.13$ to 1.95$)$. In this regard, an increased susceptibility to GCA was observed in individuals carrying the IL18-1297 C/C or the IL18-1297 C/T genotypes compared with those carrying the IL18-1297 T/T genotype (IL18-1297 C/C plus IL18-1297 T/C versus IL18$1297 \mathrm{~T} / \mathrm{T}$ genotype in GCA patients compared with controls: $P=0.005 ; \mathrm{OR}, 1.61 ; 95 \% \mathrm{Cl}, 1.15$ to 2.25$)$. We also found an additive effect of the IL18-1297 and -607 polymorphisms with TLR4 Asp299Gly polymorphism. The OR for GCA was 1.95 for combinations of genotypes with one or two risk alleles, whereas carriers of three or more risk alleles have an OR of 3.7.
\end{abstract}

Conclusions: Our results show for the first time an implication of $1 / 18$ gene-promoter polymorphisms in the susceptibility to biopsy-proven GCA. In addition, an additive effect between the associated IL18 and TLR4 genetic variants was observed.

\section{Introduction}

Giant cell, arteritis (GCA) is a large- and medium-sized blood vessel systemic vasculitis characterized by the granulomatous involvement of the aorta and especially its cranial branches [1]. GCA is now considered the most common systemic vasculitis in elderly individuals from Western countries [2,3]. Dendritic cells localized at the adventitia-media border of normal medium-sized

\footnotetext{
* Correspondence: martin@ipb.csic.es

+ Contributed equally

'Instituto de Parasitología y Biomedicina Lopez-Neyra, CSIC, Parque Tecnológico de Ciencias de la Salud, Avenida del Conocimiento s/n Armilla, Granada-18100, Spain
}

arteries play a critical role in the initiation of this vasculitis [4]. The inflammatory activity of vascular lesions in GCA is mediated by adaptive immune responses, with $\mathrm{CD} 4 \mathrm{~T}$ cells undergoing clonal expansion in the vessel wall and releasing interferon (IFN)- $\gamma$ [4]. In the experimental mouse model of GCA, systemic administration of ligands for Toll-like receptor (TLR) 2 or TLR4 in human artery-SCID chimeras led to differentiation of adventitial dendritic cells into chemokine-producing effector cells with high-level expression of both CD83 and CD86 and mediated T-cell recruitment through release of interleukin (IL)-18 [4]. GCA is also known to 
be associated with upregulation of IFN- $\gamma$, which is critically involved in modulating the process of intimal hyperplasia, leading to the severe ischemic complications observed in this vasculitis [5]. Interestingly, IFN- $\gamma$ activity is promoted by IL-18, a proinflammatory cytokine, member of the IL-1 cytokine family, which has been shown to exert innate and acquired immune responses $[6,7]$. IL-18 is expressed by a wide range of immune cells [8] and can mediate both Th1 and Th2 driven immune responses $[9,10]$. Of potential implication in GCA, IL-18 in combination with IL-12, induces IFN- $\gamma$ production in Th1 cells, B cells, and natural killer cells, promoting Th1-type immune responses $[11,12]$. However, IL-18 may also stimulate Th2 immune responses in the absence of IL-12 $[13,14]$.

GCA is a complex polygenic disease [15]. Besides a strong association of GCA with genes that lie within the major histocompatibility complex (MHC) [16-21], many other studies have shown the implication of genetic variants in key components of immune and inflammatory pathways in GCA susceptibility or clinical expression of this vasculitis [21-34].

IL18 gene is located on chromosome 11q22.2-22.3 [35] and several polymorphisms within the IL18 promoter gene have been associated with different inflammatory and autoimmune diseases [36-43].

An important step forward in our understanding of the pathogenesis of autoimmune diseases may be to establish the presence of shared mechanisms that may lead to a variety of very different complex autoimmune diseases. Taking all these considerations together, in this study we sought to establish the potential role of three polymorphisms $(-137,-607,-1297)$ within the promoter of the IL18 gene in the susceptibility to biopsy-proven GCA.

\section{Materials and methods Patients}

In total, 212 patients diagnosed with biopsy-proven GCA and 405 controls were included in this study. All of the patients fulfilled the 1990 American College of Rheumatology criteria for the classification of GCA [44]. Inclusion criteria [45] and clinical features of the patient population were described previously [46]. Also, definitions for specific features of the disease, such as polymyalgia rheumatica (PMR), visual ischemic complications, or other severe ischemic manifestations, have been previously described $[47,48]$. In all cases, biopsy-proven GCA patients were initially treated with prednisone, 40-60 mg/day, for 3 to 4 weeks. Methyl-prednisolone boluses ( $1 \mathrm{~g}$ daily for 3 days) followed by 60 -mg prednisone/day for 3 to 4 weeks were used in most patients who had visual ischemic complications or strokes. The prednisone dose was progressively tapered until discontinuation. Apart from visual complications or strokes that were irreversible in some cases, other typical features of the disease such as headache, asthenia, jaw claudication, or PMR improved after corticosteroid therapy. A decrease of erythrocyte sedimentation rate was observed in all cases after the onset of corticosteroid therapy.

Patients and controls are Caucasians, with at least two previous generations born in the corresponding regions, and were included in this study after written informed consent. We obtained approval for the study from the local ethical committees.

\section{IL18 polymorphisms selection}

Several variations within the $I L 18$ gene promoter region are responsible for changes in the transcription rate $[49,50]$. In the present study, we selected two functional IL18 promoter polymorphisms (IL18 -137 and -607), which were suggested to alter the IL18 promoter activity. To investigate further into genetic variants within the IL18 promoter region, we observed in the database [51] a variant in this region that could have a potential role in IL-18 expression (IL18-1297 or rs360719). We also studied this polymorphism based on the minor allele frequency and its ability to bind the transcription factor Oct-1. Location of the polymorphisms site was based on the GenBank Accession Nos. [Genbank: AB015961] and [Genbank:BC007461] as the reference sequence. Interestingly, we recently confirmed that the IL18-1297 gene polymorphism has a functional association with systemic lupus erythematosus [52].

\section{IL18 genotyping methods}

DNA was obtained from peripheral blood mononuclear cells, by using standard methods. The genotyping of the three IL18 polymorphisms was performed by using predesigned TaqMan SNP Genotyping Assays (Applied Biosystems, Foster City, CA), as previously described [52].

\section{Statistical analysis}

We used the $\chi^{2}$ test for Hardy-Weinberg equilibrium and statistical analysis to compare allelic and genotypic distributions. Genotype distribution was assessed by using the $\chi^{2}$ test. Odds ratio (ORs) and 95\% confidence intervals (95\% CIs) were calculated according to Woolf's method by using the Statcalc program (Epi Info 2002; Centers for Disease Control and Prevention, Atlanta, GA, USA). $P$ values $<0.05$ were considered statistically significant. LD was calculated by using Haploview v 4.0. A logistic regression model was used to estimate genegene interaction between the IL18 and TLR4 SNPs and for the additive effects of the three SNPs. Fisher's Exact test was used to test for the difference in $I L 18$ and 
TLR4 -risk allele counts between Cases and Controls. Logistic regression analyses were performed by using the software STATA (v.10.1).

\section{Results}

IL18 gene polymorphisms are associated with susceptibility to GCA

The case/control ratio was 1:2, approximately. The estimated power of this study for an estimated OR between 1.5 and 2.0 was $77 \%$ to $99.5 \%$.

No evidence of departure from Hardy-Weinberg equilibrium was observed in controls.

Table 1 shows the allele and genotype frequencies of the IL18 -137 G>C, $-607 \mathrm{C}>\mathrm{A}$, and $-1,297 \mathrm{~T}>\mathrm{C}$ polymorphisms in biopsy-proven GCA patients and healthy subjects.

No significant association between the IL18 -137 G>C and GCA was observed. However, when the IL18 -607 $\mathrm{C}>\mathrm{A}$ was assessed, we found that the frequency of allele A was significantly increased in biopsy-proven GCA patients compared with controls (47.8\% versus $40.9 \%$, respectively; $P=0.02$; OR, 1.32; 95\% CI, 1.04-1.69). It was due to a significantly increased frequency of homozygosity for the IL18 -607 A/A genotype in the group of patients with biopsy-proven GCA compared with controls (20.4\% versus 13.8 in patients and controls, respectively; IL18 -607 A/A homozygous versus $I L 18$ $-607 \mathrm{C} / \mathrm{A}$ plus IL18 -607 C/C: $P=0.04$; OR, 1.59; 95\% CI, 1.02-2.46) (Table 1).

Interestingly, a significant association between biopsyproven GCA and the IL18-1297 T>C was also found. In this regard, the $I L 18-1297$ allele C frequency was significantly increased in biopsy-proven GCA patients (30.7\%) compared with controls $(23.0 \%)(P=0.003$; OR, 1.48; 95\% CI, 1.13-1.95) (Table 1). Moreover, the genotype distribution of the IL18-1297 T>C polymorphism disclosed statistically significant differences between biopsy-proven GCA patients and controls $(P=0.011)$. It was due to a reduced frequency of individuals carrying the IL18-1297 T/T genotype in the group of biopsy-proven GCA patients (46.7\%) compared with the controls (58.5\%). In this regard, an increased susceptibility to GCA was observed in individuals carrying the IL18-1297 $\mathrm{C} / \mathrm{C}$ or the IL18-1297 C/T genotypes (IL18-1297 C/C) plus $\mathrm{T} / \mathrm{C}$ genotypes versus $\mathrm{T} / \mathrm{T}$ genotype in GCA patients compared with controls: $P=0.005$; OR, 1.61; 95\% CI, 1.15-2.25). We did not perform a haplotype analysis because the most associated SNP rs360719 $(-1297)$ is not located in a haplotype block, but is a singleton.

Table 1 IL18 gene polymorphisms in a series of biopsy-proven GCA and matched controls

\begin{tabular}{|c|c|c|c|c|}
\hline $\begin{array}{l}\text { IL18 } \\
\text { Polymorphisms }\end{array}$ & $\begin{array}{l}\text { GCA patients } \\
\text { Number (\%) }\end{array}$ & $\begin{array}{l}\text { Healthy controls } \\
\text { Number }(\%)\end{array}$ & & \\
\hline-137 (G->C) (rs187238) & Number $=212$ & Number $=403$ & $P$ value & OR $(95 \% \mathrm{Cl})$ \\
\hline$\overline{G / G}$ & $106(50.0)$ & $224(55.6)$ & Reference & - \\
\hline $\mathrm{G} / \mathrm{C}$ & $94(44.3)$ & $159(39.4)$ & 0.20 & $1.25(0.87-1.79)$ \\
\hline $\mathrm{C} / \mathrm{C}$ & $12(5.7)$ & $20(5.0)$ & 0.53 & $1.27(0.56-2.84)$ \\
\hline G & $306(72.2)$ & $607(75.3)$ & Reference & - \\
\hline C & $118(27.8)$ & $199(24.7)$ & 0.23 & $1.18(0.89-1.55)$ \\
\hline$-607(C->A)(r s 1946518)^{a}$ & Number $=212$ & Number $=405$ & $P$ value & OR $(95 \% \mathrm{Cl})$ \\
\hline $\mathrm{C} / \mathrm{C}$ & $53(24.9)$ & $129(31.9)$ & Reference & - \\
\hline$C / A$ & $116(54.7)$ & $220(54.3)$ & 0.21 & $1.28(0.85-1.94)$ \\
\hline$A / A$ & $43(20.4)$ & $56(13.8)$ & 0.02 & $1.87(1.09-3.21)$ \\
\hline C & $221(52.2)$ & $478(59.1)$ & Reference & \\
\hline A & $203(47.8)$ & $332(40.9)$ & 0.02 & $1.32(1.04-1.69)$ \\
\hline$-1297(\mathrm{~T}->\mathrm{C})(\mathrm{rs} 360719)^{\mathrm{b}}$ & Number $=212$ & Number $=405$ & $P$ value & OR $(95 \% \mathrm{Cl})$ \\
\hline$\overline{\mathrm{T} / \mathrm{T}}$ & $99(46.7)$ & $237(58.5)$ & Reference & - \\
\hline $\mathrm{T} / \mathrm{C}$ & $96(45.3)$ & $150(37.0)$ & 0.02 & $1.53(1.07-2.20)$ \\
\hline $\mathrm{C} / \mathrm{C}$ & $17(8.0)$ & $18(4.4)$ & 0.02 & $2.26(1.063-4.82)$ \\
\hline $\mathrm{T}$ & $294(69.3)$ & $624(77.0)$ & Reference & \\
\hline C & $130(30.7)$ & $186(23.0)$ & 0.003 & $1.48(1.13-1.95)$ \\
\hline
\end{tabular}

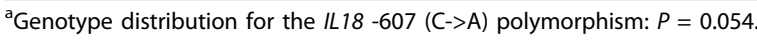

${ }^{\mathrm{b}}$ Genotype distribution for the IL18 -1297 (T->C) (rs360719): $P=0.011$.

Genotype frequencies for the IL18 -607 (C->A) (rs1946518) polymorphism: IL18 -607 A/A homozygous versus IL18 -607 C/A plus IL18 -607 C/C: P = 0.04; OR, 1.59; $95 \% \mathrm{Cl}, 1.02-2.46$.

Genotype frequencies for the IL18-1297 (T->C) (rs360719) polymorphism: IL18-1297 C/C plus IL18-1297 T/C genotypes compared to IL18-1297 T/T genotype: $P=0.005 ;$ OR, $1.61 ; 95 \% \mathrm{Cl}, 1.15-2.25$ 


\section{IL18 gene polymorphisms are not associated with clinical manifestation of GCA patients}

In a further step, we stratified GCA patients according to the presence of PMR, visual ischemic complications, and severe ischemic manifestations. However, no significant differences were observed when GCA patients were compared according to the presence or absence of these specific clinical features of the disease (data not shown).

\section{Additive effects of the IL18 and TLR4 risk alleles in GCA}

We recently reported an association between the TLR4 Asp299Gly polymorphism and GCA in our population [46]. In the present study, we investigated the potential combined effect of the risk IL18 and TLR4 alleles on GCA susceptibility by using an additive logistic regression model. The distribution of the different combinations of IL18 and TLR4 risk alleles in GCA patients and controls is shown in Additional file 1. The overall difference in risk allele counts between GCA patients and controls was statistical significance, $P=0.01$. We observed an additive effect of risk alleles on susceptibility to GCA. Figure 1 shows the OR for GCA according to the presence of one or two and three or more risk alleles among these three genetic variants, by using the individuals with zero risk allele as the reference group. As shown in the figure, the risk of GCA increases as a function of the number of risk alleles, in an additive manner. Thus, the OR for GCA is 1.9 (CI, 1.1-2.3) for carriers of one or two risk alleles, and 3.7 (CI, 1.9-7.2) for carriers of three or more risk alleles.

\section{Discussion}

In the present study, we examined for the first time the contribution of three polymorphisms in the promoter region of the IL18 gene for the susceptibility to GCA. Our results support a potential role of the IL18 -607 $\mathrm{C}>\mathrm{A}(\mathrm{rs} 1946518)$ and the IL18-1297 T>C (rs360719) gene polymorphisms in the predisposition to biopsyproven GCA. Individuals carrying the IL18 -607 A/A showed an increased risk of having GCA compared with controls. A protective effect against the development of GCA was found in individuals carrying the IL18-1297 $\mathrm{T} / \mathrm{T}$ genotype. In contrast, an increased risk of GCA was observed in individuals carrying the IL18-1297 allele C.

Proinflammatory cytokines play a major role in the pathogenesis of GCA [53], a disease associated with a high inflammatory response [54]. IL-18 is a proinflammatory cytokine that induces $\mathrm{T}$-helper 1 differentiation and has cytotoxic T-lymphocyte functions. IL-18 has also emerged as a pivotal cytokine in different autoimmune diseases [55]. A number of functional polymorphisms within the proximal promoter of the IL18 gene that may interfere with transcription-factor-binding sites have been verified $[49,50]$. The implication of the IL18 $-1297 \mathrm{~T}>\mathrm{C}$ polymorphism in the susceptibility to GCA also has functional relevance because recent data from our group confirmed that the relative quantification of mRNA performed in total RNA from 23 healthy individuals carrying different genotypes for IL18 -1297 T>C (rs360719) polymorphism was associated with an increased expression in individuals carrying the $\mathrm{C}$ allele

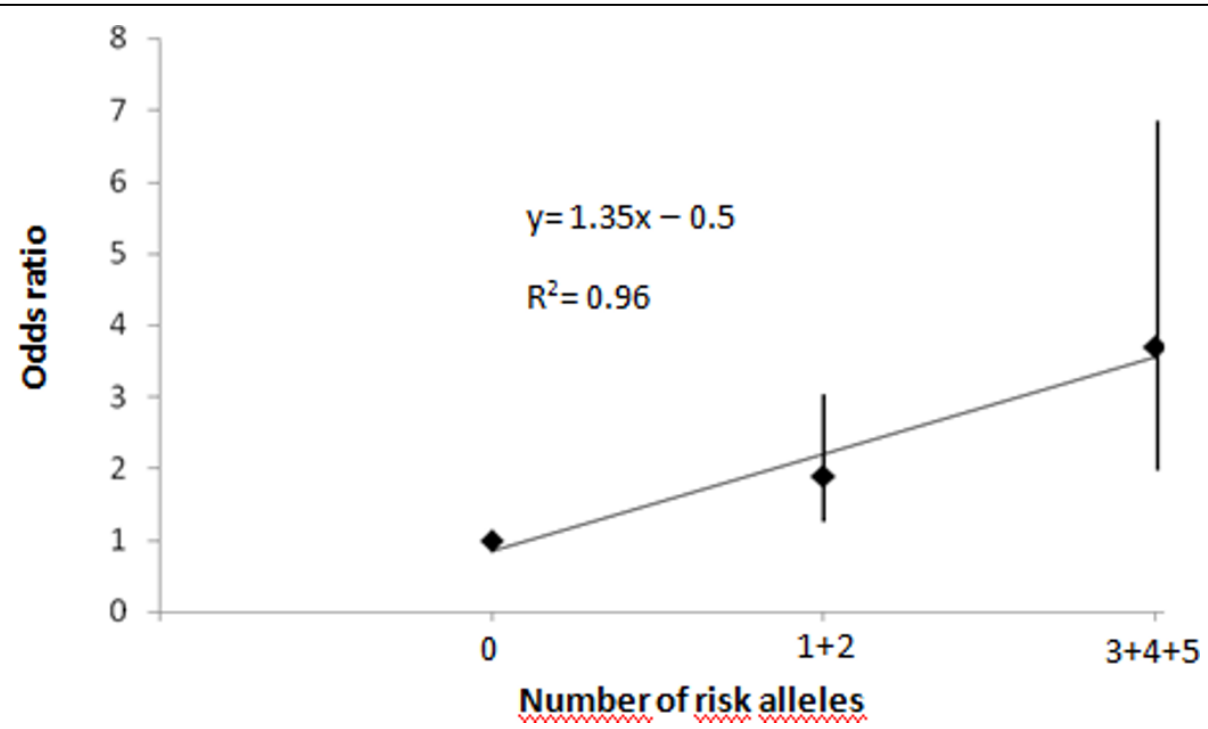

Figure 1 Combined effects of the risk alleles of (IL18 -607 and -1297) and TLR4 (Asp299Gly) on susceptibility to GCA. Linear regression analysis showed an additive effect of the risk alleles of the IL18 and TLR4 on GCA susceptibility. The ORs with 95\% Cl are shown as a function of number of risk alleles of GCA. 
(CC+CT versus TT) [52]. Interestingly, Nabili et al. [56] reported and increased expression of IL18 in temporal artery biopsies of GCA patients, with no correlation with clinical manifestations or hematologic parameters. All these data are in accordance with our results and support a potential role of these gene variants in the susceptibility to GCA but not in the phenotypic expression of this vasculitis.

It has been proposed that a variety of inflammatory and autoimmune diseases may share common pathogenic mechanisms. IL18 promoter gene polymorphisms have been associated with several autoimmune diseases. With respect to this, an association of the $I L 18-137$ G>C [rs187238] but not the IL18 -607 C>A (rs1946518) gene polymorphism with susceptibility to type I diabetes was reported in a study [39]. However, another study of the same two promoter polymorphisms in patients with type I diabetes showed an increased frequency of IL18 -607 CA genotype compared with control subjects, but no significant difference in the IL18 -137 allele frequencies [57]. No significant association was found when the IL18 - $137 \mathrm{G}>\mathrm{C}(\mathrm{rs} 187238)$ and the IL18 -607 C>A (rs1946518) gene polymorphisms were studied in patients with multiple sclerosis, Crohn disease, or ulcerative colitis $[50,58]$.

In keeping with the results derived from a study on Spanish individuals diagnosed with rheumatoid arthritis (RA) [59], in the present study, we did not find a significant association between the IL18 -137 (rs187238) polymorphism and biopsy-proven GCA.

A protective effect mediated by the IL18 -607 A/A genotype was observed in Asian patients with RA [43]. It was not the case for Spanish individuals with RA [59]. However, according to our results, an association exists between biopsy-proven GCA and the IL18 -607 (rs1946518) gene polymorphism. Moreover, our data show an additional association of biopsy-proven GCA with IL18 -1297 T>C (rs360719).

Taken together, the different results in terms of disease susceptibility mediated by the IL18 gene polymorphisms in different autoimmune diseases support the notion that different pathogenic mechanisms are involved in the development of polygenic diseases.

Although our data show a clear association of these polymorphisms with GCA susceptibility in the Spanish population, further studies in other populations with different genetic backgrounds are needed to clarify fully the implication of IL18 promoter polymorphisms in GCA susceptibility. However, most genetic associations reported in Spanish patients with GCA also have been replicated in other populations, such as $H L A-D R B 1$ in North American [16,17], Danish [21], French [60], and Swiss [61], and $I L-6$ promoter and eNOS polymorphisms, in Italians $[24,28]$. This evidence may indicate a high reproducibility of the genetic associations with GCA among different populations and that the potential association with IL18 may be also found in other populations. Nevertheless, the lack of genome-wide association studies or whole-genome-scan linkage studies in GCA makes necessary an independent replication study to confirm our results by using a population of a different genetic background.

When we determined the joint effect of the risk alleles of IL18 and TLR4, we observed a considerably increased risk of GCA (OR, 3.7) for those 25\% GCA patients who carried three or more risk alleles compared with those who carried none. Interestingly, this OR was higher than that obtained for any IL18 or TLR4 SNPs individually (OR, 1.37 for $I L 18-607$; OR, 1.48 for $I L 18$-1297, and OR, 1.65 for TLR $4+896 \mathrm{G}$ allele). The additive effect observed between IL18 and TLR4 suggests that combining information from common risk polymorphisms could improve disease prediction. These observations, as well as the findings showing that IL18 and TLR4 genetic variants are associated with other autoimmune diseases [33,39-41,50,52,62-64], support the pivotal role of innate immunity in the development of autoimmunity and GCA. Nevertheless, further studies in other populations are required to validate our findings.

\section{Conclusions}

The present study shows for the first time that $I L 18$ gene promoter polymorphisms are associated with susceptibility to biopsy-proven GCA. In addition, an additive effect between the risk IL18 and TLR4 alleles was observed.

Additional file 1: Supplementary table. Distribution of IL18/TLR4 genotype combinations in GCA patients and controls.

\section{Abbreviations}

Cl: confidence interval; GCA: giant cell arteritis; IL18: interleukin 18; OR: odds ratio; SNP: single-nucleotide polymorphism; TLR4: Toll-like receptor 4.

\section{Acknowledgements}

We thank Sofia Vargas and Gema Robledo for their invaluable contribution in the collection, isolation, and storage of the DNA samples. We also thank Sara Abel Liz, Maria Soledad Folgosa Rodriguez, and Ana Maria Ramos Gandoy, nurses from the Rheumatology Division (Hospital Xeral-Calde, Lugo, Spain) for their valuable help in the collection of samples. This study was supported by a grant from Fondo de Investigaciones Sanitarias PI06-0024 (Spain) and in part by Junta de Andalucía, grupo CTS-180 (Spain). This work was partially supported by the RETICS Program, RD08/0075 (RIER), from Instituto de Salud Carlos III (ISCIII).

\section{Author details}

${ }^{1}$ Instituto de Parasitología y Biomedicina Lopez-Neyra, CSIC, Parque Tecnológico de Ciencias de la Salud, Avenida del Conocimiento s/n Armilla, Granada-18100, Spain. ²Division of Rheumatology, Hospital Xeral-Calde, c/Dr. Ochoa, Lugo 27004, Spain. ${ }^{3}$ Rheumatology Service, Hospital Clínico San Carlos, c/Profesor Martín Lagos, S/N Madrid - 28040, Spain. ${ }^{4}$ Department of Rheumatology, Hospital de la Princesa, Universidad Autónoma, c/Diego de 
León 62, Madrid, 28006, Spain. ${ }^{5}$ Department of Internal Medicine, Hospital Clínico San Cecílio, Avenida Doctor Olóriz 16 Granada 18012, Spain. ${ }^{6}$ Division of Rheumatology, Hospital Universitario Marques de Valdecilla, Santander39008, Spain.

\section{Authors' contributions}

RPM carried out genotyping, participated in the design of the study, data analysis, and helped to draft the manuscript. TRV participated in the acquisition and interpretation of data and in the design of the study. OT participated in the acquisition and interpretation of data. ICM participated in the acquisition and interpretation of data. SC has been involved in the acquisition and interpretation of data and in revising it critically for important intellectual content. JAM participated in the acquisition and interpretation of data. JLC participated in the acquisition and interpretation of data. BF has been involved in the acquisition and interpretation of data and in revising it critically for important intellectual content. MAG-G made substantial contributions to the conception and design of the study, acquisition of data, coordination, helped to draft the manuscript, and gave final approval of the version to be published. JM made substantial contributions to the conception and design of the study, acquisition of data, and coordination, helped to draft the manuscript, and gave final approval of the version to be published.

\section{Competing interests}

The authors declare that they have no competing interests.

Received: 10 September 2009 Revised: 2 March 2010

Accepted: 23 March 2010 Published: 23 March 2010

\section{References}

1. Salvarani C, Cantini F, Boiardi L, Hunder GG: Polymyalgia rheumatica and giant-cell arteritis. N Engl J Med 2002, 347:261-271.

2. Gonzalez-Gay MA, Garcia-Porrua C: Epidemiology of the vasculitides. Rheum Dis Clin North Am 2001, 27:729-749.

3. Gonzalez-Gay MA, Vazquez-Rodriguez TR, Lopez-Diaz MJ, Miranda-Filloy JA, Gonzalez-Juanatey C, Martin J, Llorca J: Epidemiology of giant cell arteritis and polymyalgia rheumatica. Arthritis Rheum 2009, 61:1454-1461.

4. Weyand CM, Ma-Krupa W, Pryshchep O, Gröschel S, Bernardino R, Goronzy JJ: Vascular dendritic cells in giant cell arteritis. Ann N Y Acad Sci 2005, 1062:195-208.

5. Weyand $\mathrm{CM}$, Goronzy Jj: The Dunlop-Dottridge Lecture: the pathogenesis of giant cell arteritis. J Rheumatol 2000, 27:517-522.

6. Gracie JA, Robertson SE, McInnes IB: Interleukin-18. J Leukoc Biol 2003, 73:213-224.

7. McInnes IB, Gracie JA, Leung BP, Wei XQ, Liew FY: Interleukin 18: a pleiotropic participant in chronic inflammation. Immunol Today 2000, 21:312-315.

8. Dinarello CA: Interleukin-18. Methods 1999, 19:121-132.

9. Nakanishi K, Yoshimoto T, Tsutsui H, Okamura H: Interleukin-18 regulates both Th1 and Th2 responses. Annu Rev Immunol 2001, 19:423-474.

10. Nakanishi K, Yoshimoto T, Tsutsui H, Okamura H: Interleukin-18 is a unique cytokine that stimulates both Th1 and Th2 responses depending on its cytokine milieu. Cytokine Growth Factor Rev 2001, 12:53-72.

11. Yoshimoto T, Takeda K, Tanaka T, Ohkusu K, Kashiwamura S, Okamura H, Akira S, Nakanishi K: IL-12 up-regulates IL-18 receptor expression on T cells, Th1 cells, and B cells: synergism with IL-18 for IFN-gamma production. J Immunol 1998, 161:3400-3407.

12. Tominaga $\mathrm{K}$, Yoshimoto T, Torigoe K, Kurimoto M, Matsui K, Hada T, Okamura H, Nakanishi K: IL-12 synergizes with IL-18 or IL-1beta for IFNgamma production from human T cells. Int Immunol 2000, 12:151-160.

13. Yoshimoto T, Mizutani H, Tsutsui H, Noben-Trauth N, Yamanaka K, Tanaka M, Izumi S, Okamura H, Paul WE, Nakanishi K: IL-18 induction of IgE: dependence on CD4+ T cells, IL-4 and STAT6. Nat Immunol 2000, 1:132-137.

14. Yoshimoto T, Tsutsui H, Tominaga K, Hoshino K, Okamura H, Akira S, Paul WE, Nakanishi K: IL-18, although antiallergic when administered with IL-12, stimulates IL-4 and histamine release by basophils. Proc Natl Acad Sci USA 1999, 96:13962-13966.

15. Gonzalez-Gay MA, Amoli MM, Garcia-Porrua C, Ollier WE: Genetic markers of disease susceptibility and severity in giant cell arteritis and polymyalgia rheumatica. Semin Arthritis Rheum 2003, 33:38-48.
16. Weyand CM, Hicok KC, Hunder GG, Goronzy Jj: The HLA-DRB1 locus as a genetic component in giant cell arteritis: mapping of a disease-linked sequence motif to the antigen binding site of the HLA-DR molecule. J Clin Invest 1992, 90:2355-2361.

17. Weyand CM, Hunder NN, Hicok KC, Hunder GG, Goronzy JJ: HLA-DRB1 alleles in polymyalgia rheumatica, giant cell arteritis, and rheumatoid arthritis. Arthritis Rheum 1994, 37:514-520.

18. Dababneh A, Gonzalez-Gay MA, Garcia-Porrua C, Hajeer A, Thomson W, Ollier W: Giant cell arteritis and polymyalgia rheumatica can be differentiated by distinct patterns of HLA class II association. J Rheumatol 1998, 25:2140-2145.

19. Mattey DL, Hajeer AH, Dababneh A, Thomson W, González-Gay MA, GarcíaPorrúa C, Ollier WE: Association of giant cell arteritis and polymyalgia rheumatica with different tumor necrosis factor microsatellite polymorphisms. Arthritis Rheum 2000, 43:1749-1755.

20. Gonzalez-Gay MA, Rueda B, Vilchez JR, Lopez-Nevot MA, Robledo G, Ruiz MP, Fernández O, Garcia-Porrua C, Gonzalez-Escribano MF, Martín J: Contribution of MHC class I region to genetic susceptibility for giant cell arteritis. Rheumatology 2007, 46:431-434.

21. Jacobsen S, Baslund B, Madsen HO, Tvede N, Svejgaard A, Garred P: Mannose-binding lectin variant alleles and HLA-DR4 alleles are associated with giant cell arteritis. J Rheumatol 2002, 29:2148-21453.

22. Gonzalez-Gay MA, Hajeer AH, Dababneh A, Garcia-Porrua C, Amoli MM, Llorca J, Ollier WE: Interferon-gamma gene microsatellite polymorphisms in patients with biopsy-proven giant cell arteritis and isolated polymyalgia rheumatica. Clin Exp Rheumatol 2004, 22(6 Suppl 36):S18-S20.

23. Gonzalez-Gay MA, Hajeer AH, Dababneh A, Garcia-Porrua C, Mattey DL, Amoli MM, Thomson W, Ollier WE: IL-6 promoter polymorphism at position -174 modulates the phenotypic expression of polymyalgia rheumatica in biopsy-proven giant cell arteritis. Clin Exp Rheumatol 2002, 20:179-184.

24. Salvarani C, Casali B, Farnetti E, Pipitone N, Nicoli D, Macchioni P, Cimino L, Bajocchi G, Catanoso MG, Boiardi L: Interleukin-6 promoter polymorphism at position -174 in giant cell arteritis. J Rheumatol 2005, 32:2173-2177.

25. Boiardi L, Casali B, Farnetti E, Pipitone N, Nicoli D, Macchioni P, Cimino L, Bajocchi G, Catanoso MG, Pattacini L, Salvarani C: Interleukin-10 promoter polymorphisms in giant cell arteritis. Arthritis Rheum 2006, 54:4011-4017.

26. Rueda B, Roibas B, Martin J, Gonzalez-Gay MA: Influence of interleukin 10 promoter polymorphisms in susceptibility to giant cell arteritis in Northwestern Spain. J Rheumatol 2007, 34:1535-1539.

27. Salvarani C, Casali B, Boiardi L, Ranzi A, Macchioni P, Nicoli D, Farnetti E, Brini M, Portioli I: Intercellular adhesion molecule 1 gene polymorphisms in polymyalgia rheumatica/giant cell arteritis: association with disease risk and severity. J Rheumatol 2000, 27:1215-1221.

28. Salvarani C, Casali B, Nicoli D, Farnetti E, Macchioni P, Catanoso MG, Chen Q, Bajocchi G, Boiardi L: Endothelial nitric oxide synthase gene polymorphisms in giant cell arteritis. Arthritis Rheum 2003, 48:3219-3223.

29. Amoli MM, Garcia-Porrua C, Llorca J, Ollier WE, Gonzalez-Gay MA: Endothelial nitric oxide synthase haplotype associations in biopsyproven giant cell arteritis. J Rheumatol 2003, 30:2019-2022.

30. Gonzalez-Gay MA, Oliver J, Sanchez E, Garcia-Porrua C, Paco L, LopezNevot MA, Ollier WE, Martin J: Association of a functional inducible nitric oxide synthase promoter variant with susceptibility to biopsy-proven giant cell arteritis. J Rheumatol 2005, 32:2178-2182.

31. Rueda B, Lopez-Nevot MA, Lopez-Diaz MJ, Garcia-Porrua C, Martín J, Gonzalez-Gay MA: A functional variant of vascular endothelial growth factor is associated with severe ischemic complications in giant cell arteritis. J Rheumatol 2005, 32:1737-1741.

32. Morgan AW, Robinson JI, Barrett JH, Martin J, Walker A, Babbage SJ, Ollier WE, Gonzalez-Gay MA, Isaacs JD: Association of FCGR2A and FCGR2A-FCGR3A haplotypes with susceptibility to giant cell arteritis. Arthritis Res Ther 2006, 8:R109.

33. Rueda B, Miranda-Filloy JA, Martin J, Gonzalez-Gay MA: Association of CD24 gene polymorphisms with susceptibility to biopsy-proven giant cell arteritis. J Rheumatol 2008, 35:850-854.

34. Rodríguez-Pla A, Beaty TH, Savino PJ, Eagle RC Jr, Seo P, Soloski MJ: Association of a nonsynonymous single-nucleotide polymorphism of matrix metalloproteinase 9 with giant cell arteritis. Arthritis Rheum 2008, 58:1849-1853. 
35. Nolan KF, Greaves DR, Waldmann H: The human interleukin 18 gene IL18 maps to 11q22.2-q22.3, closely linked to the DRD2 gene locus and distinct from mapped IDDM loci. Genomics 1998, 51:161-163.

36. Higa S, Hirano T, Mayumi M, Hiraoka M, Ohshima Y, Nambu M, Yamaguchi E, Hizawa N, Kondo N, Matsui E, Katada Y, Miyatake A, Kawase I, Tanaka T: Association between interleukin-18 gene polymorphism 105A/ C and asthma. Clin Exp Allergy 2003, 33:1097-1102.

37. Imboden M, Nicod L, Nieters A, Glaus E, Matyas G, Bircher AJ, AckermannLiebrich U, Berger W, Probst-Hensch NM, SAPALDIA Team: The common Gallele of interleukin-18 single-nucleotide polymorphism is a genetic risk factor for atopic asthma: The SAPALDIA Cohort Study. Clin Exp Allergy 2006, 36:211-218.

38. Tiret L, Godefroy T, Lubos E, Nicaud V, Tregouet DA, Barbaux S, Schnabel R, Bickel C, Espinola-Klein C, Poirier O, Perret C, Münzel T, Rupprecht HJ, Lackner K, Cambien F, Blankenberg S, Athero Gene Investigators: Genetic analysis of the interleukin-18 system highlights the role of the interleukin-18 gene in cardiovascular disease. Circulation 2005, 112:643-650.

39. Kretowski A, Mironczuk K, Karpinska A, Bojaryn U, Kinalski M, Puchalski Z, Kinalska I: Interleukin-18 promoter polymorphisms in type 1 diabetes. Diabetes 2002, 51:3347-3349.

40. Mojtahedi Z, Naeimi S, Farjadian S, Omrani GR, Ghaderi A: Association of IL-18 promoter polymorphisms with predisposition to Type 1 diabetes. Diabet Med 2006, 23:235-239.

41. Sugiura T, Maeno N, Kawaguchi $Y$, Takei S, Imanaka H, Kawano Y, TerajimaIchida H, Hara M, Kamatani N: A promoter haplotype of the interleukin-18 gene is associated with juvenile idiopathic arthritis in the Japanese population. Arthritis Res Ther 2006, 8:R60.

42. Tamura K, Fukuda Y, Sashio H, Takeda N, Bamba H, Kosaka T, Fukui S, Sawada K, Tamura K, Satomi M, Yamada T, Yamamura T, Yamamoto $Y$ Furuyama J, Okamura H, Shimoyama T: IL18 polymorphism is associated with an increased risk of Crohn's disease. J Gastroenterol 2002, 37:111-116.

43. Sivalingam SP, Yoon KH, Koh DR, Fong KY: Single-nucleotide polymorphisms of the interleukin-18 gene promoter region in rheumatoid arthritis patients: protective effect of AA genotype. Tissue Antigens 2003, 62:498-504.

44. Hunder GG, Bloch DA, Michel BA, Stevens MB, Arend WP, Calabrese LH, Edworthy SM, Fauci AS, Leavitt RY, Lie JT, Lightfoot RW Jr, Masi AT, et al: The American College of Rheumatology 1990 criteria for the classification of giant cell arteritis. Arthritis Rheum 1990, 33:1122-8.

45. Gonzalez-Gay MA, Garcia-Porrua C, Llorca J, Gonzalez-Louzao C, RodriguezLedo P: Biopsy-negative giant cell arteritis: clinical spectrum and predictive factors for positive temporal artery biopsy. Semin Arthritis Rheum 2001, 30:249-256

46. Palomino-Morales $\mathrm{R}$, Torres O, Vazquez-Rodriguez TR, Morado IC, Castañeda S, Callejas-Rubio JL, Miranda-Filloy JA, Fernandez-Gutierrez B, Martin J, Gonzalez-Gay MA: Association between Toll-like receptor 4 gene polymorphism and biopsy-proven giant cell arteritis. J Rheumatol 2009, 36:1501-1506.

47. Gonzalez-Gay MA, Garcia-Porrua C, Vazquez-Caruncho M: Polymyalgia rheumatica in biopsy proven giant cell arteritis does not constitute a different subset but differs from isolated polymyalgia rheumatica. J Rheumatol 1998, 25:1750-1755.

48. Gonzalez-Gay MA, Pineiro A, Gomez-Gigirey A, Garcia-Porrua C, PegoReigosa R, Dierssen-Sotos T, Llorca J: Influence of traditional risk factors of atherosclerosis in the development of severe ischemic complications in giant cell arteritis. Medicine (Baltimore) 2004, 83:342-347.

49. Tone M, Thompson SA, Tone Y, Fairchild PJ, Waldmann H: Regulation of IL18 (IFN-gamma-inducing factor) gene expression. J Immunol 1997, 159:6156-6163.

50. Giedraitis V, He B, Huang WX, Hillert J: Cloning and mutation analysis of the human IL-18 promoter: a possible role of polymorphisms in expression regulation. J Neuroimmunol 2001, 112:146-152.

51. PubMed. [http://www.ncbi.nlm.nih.gov/sites/entrez].

52. Sánchez E, Palomino-Morales RJ, Ortego-Centeno N, Jiménez-Alonso J, González-Gay MA, López-Nevot MA, Sánchez-Román J, de Ramón E, González-Escribano MF, Pons-Estel BA, D'Alfonso S, Sebastiani GD, Italian collaborative group, Alarcón-Riquelme ME, Martín J: Identification of a new putative IL 18 gene variant through a functional and association study in systemic lupus erythematosus. Hum Mol Genet 2009, 18:3739-3748.
53. Weyand CM, Hicok KC, Hunder GG, Goronzy JJ: Tissue cytokine patterns in patients with polymyalgia rheumatica and giant cell arteritis. Ann Intern Med 1994, 121:484-491.

54. Gonzalez-Gay MA, Lopez-Diaz MJ, Barros S, Garcia-Porrua C, SanchezAndrade A, Paz-Carreira J, Martin J, Llorca J: Giant cell arteritis: laboratory tests at the time of diagnosis in a series of 240 patients. Medicine (Baltimore) 2005, 84:277-290.

55. Thompson SR, Humphries SE: Interleukin-18 genetics and inflammatory disease susceptibility. Genes Immun 2007, 8:91-99.

56. Nabili S, Bhatt P, Roberts F, Gracie A, McFadzean R: Local expression of IL18 in the temporal artery does not correlate with clinical manifestations of giant cell arteritis. Neuro-Ophthalmology 2008, 32:3-6.

57. Ide A, Kawasaki E, Abiru N, Sun F, Kobayashi M, Fukushima T, Takahashi R, Kuwahara H, Kita A, Oshima K, Uotani S, Yamasaki H, Yamaguchi Y, Eguchi K: Association between IL-18 gene promoter polymorphisms and CTLA-4 gene 49A/G polymorphism in Japanese patients with type 1 diabetes. J Autoimmun 2004, 22:73-78.

58. Glas J, Torok HP, Tonenchi L, Kapser J, Schiemann U, Muller-Myhsok B, Folwaczny $M$, Folwaczny $C$ : Association of polymorphisms in the interleukin-18 gene in patients with Crohn's disease depending on the CARDIS15/NOD2 genotype. Inflamm Bowel Dis 2005, 11:1031-1037.

59. Rueda B, González-Gay MA, Matarán L, López-Nevot MA, Martín J: Interleukin-18-promoter polymorphisms are not relevant in rheumatoid arthritis. Tissue Antigens 2005, 65:544-548.

60. Rauzy O, Fort M, Nourhashemi F, Alric L, Juchet $H$, Ecoiffier M, Abbal M Adoue D: Relation between HLA DRB1 alleles and corticosteroid resistance in giant cell arteritis. Ann Rheum Dis 1998, 57:380-382

61. Guerne PA, Salvi M, Seitz M, Bruhlmann P, Rivier G, Frey D, Mermillod B, Vischer TL, Tiercy JM: Molecular analysis of HLA-DR polymorphism in polymyalgia rheumatica: Swiss Group for Research on HLA in Polymyalgia Rheumatica. J Rheumatol 1997, 24:671-676.

62. Radstake TR, Franke $B$, Hanssen $S$, Netea MG, Welsing $P$, Barrera $P$ Joosten $L A$, van Riel PL, Berg van den WB: The Toll-like receptor 4 Asp299Gly functional variant is associated with decreased rheumatoid arthritis disease susceptibility but does not influence disease severity and/or outcome. Arthritis Rheum 2004, 50:999-1001.

63. Franchimont D, Vermeire S, El Housni H, Pierik M, Van Steen K, Gustot T, Quertinmont E, Abramowicz M, Van Gossum A, Devière J, Rutgeerts P: Deficient host-bacteria interactions in inflammatory bowel disease? The Toll-like receptor (TLR)-4 Asp299 gly polymorphism is associated with Crohn's disease and ulcerative colitis. Gut 2004, 53:987-992.

64. Pierangeli SS, Vega-Ostertag ME, Raschi E, Liu X, Romay-Penabad Z, De Micheli V, Galli M, Moia M, Tincani A, Borghi MO, Nguyen-Oghalai T, Meroni PL: Toll-like receptor and antiphospholipid mediated thrombosis: in vivo studies. Ann Rheum Dis 2007, 66:1327-1333.

\section{doi:10.1186/ar2962}

Cite this article as: Palomino-Morales et al: Association between IL-18 gene polymorphisms and biopsy-proven giant cell arteritis. Arthritis Research \& Therapy 2010 12:R51.

\section{Submit your next manuscript to BioMed Central and take full advantage of:}

- Convenient online submission

- Thorough peer review

- No space constraints or color figure charges

- Immediate publication on acceptance

- Inclusion in PubMed, CAS, Scopus and Google Scholar

- Research which is freely available for redistribution 